\title{
Maxillary Incisor Replacement with the Ectopically Erupting Canine : Case Reports
}

\author{
Jieun Lim, Sungchul Choi, Jaehong Park, Yeongchul Choi, Kwangchul Kim, Hyojung Ann \\ Department of Pediatric Dentistry and Institute of Oral Biology, School of Dentistry, Kyung Hee University, Seoul, Korea
}

\begin{abstract}
Impacted maxillary canines are the most frequently impacted teeth after the third molars. The exact etiology of impacted maxillary canines is unknown, but several complications may result from impacted maxillary canines.

An early detection of ectopically erupting teeth can lead to performing interceptive treatment such as early extraction of primary canine and provide the best long-term results. In the absence of prevention, clinicians should consider orthodontic treatment followed by surgical exposure of the canine to bring it into occlusion. However, in cases when the finding ectopically erupting teeth and severe root resorption of adjacent teeth are found late, malposed canine can replace the injured teeth.

In these presented cases, early diagnosis and treatment of ectopic eruption and root resorption were not performed. The maxillary incisor replacement with ectopically erupting canine can be the alternative treatment of choice with successful results. The reconstructed canine is planned to be checked periodically for the condition of composite resin restoration. Orthodontic treatment and dental implant are planned.

This report shows that when early diagnosis was not done, maxillary incisor replacement with ectopically erupting canine could prevent uncertain prognosis of the adjacent teeth with root resorption and provide esthetic satisfactory with time saved and cost reduced.
\end{abstract}

Key words : Ectopic eruption, Impacted canine, Root resorption

\section{I. 서 론}

매복된 상악 견치는 제 3대구치 다음으로 흔한 매복치아로 약 $0.9 \sim 3 \%$ 의 빈도로 발생하며, 매복의 정확한 원인은 알려져 있지 않다 ${ }^{1.2)}$. 이와 같은 빈도로 발생되는 매복 견치는 인접치의 변위와 치수 생활력의 상실, 악궁 길이의 손실, 낭종의 형성, 유 착, 감염, 재발성 동통, 인접치아의 내흡수 또는 외흡수 등의 합 병증을 유발할 수 있다 ${ }^{3}$.

인접치의 흡수는 매복 견치로 인한 심각한 합병증으로 여겨 진다. 매복 견치에 의해서 가장 빈번하게 흡수가 나타나는 치아 는 상악 측절치이며, 상악 중절치 또한 영향을 받는다고 보고되
고 있다2). 전통적인 단층촬영을 이용한 10 세에서 13 세 어린이 의 상악 견치의 이소 맹출에 관한 연구 결과 대상자의 $12 \%$ 에서 인접치의 치근흡수가 관찰되었다 ${ }^{4}$. 최근 컴퓨터 단층촬영을 이 용한 유사한 연구에서 대상자 절치의 $48 \%$ 에 치근흡수가 나타났 다. 그 중 상악 측절치에서 $38 \%$ 로 가장 빈번한 치근흡수가 나 타났고, 상악 중절치는 $9 \%$ 에서 치근흡수가 나타났다 ${ }^{5}$.

매복 견치로 인한 인접치의 치근흡수는 조기 진단이 이뤄진 경우 매복치의 맹출경로의 변경을 통하여 예방할 수 있다. 그러 나 치근흡수가 심하게 진행된 상태에서 매복 견치가 발견된 경 우수술적 노출을 동반한 교정적 치료의 시행은 이미 치근이 흡 수된 치아의 문제를 해결하지 못하고 때로는 치아의 상실을 야

\section{Corresponding author : Hyojung Ann}

Department of Pediatric Dentistry and Institute of Oral Biology, School of Dentistry, Kyung Hee University, 26, Kyungheedae-ro, Dongdaemun-gu, Seoul, 130701, Korea

Tel: +82-2-958-9397 / Fax: +82-2-965-7247 / E-mail: hyojungann@naver.com

Received May 23, 2013 / Revised September 11, 2013 / Accepted September 11, 2013 
기 할 수도 있다. 따라서 매복 견치를 위한 공간이 부족한 경우 또는 교정적 발치가 예정된 환자에서 심하게 흡수된 치아의 발 치가 일반적인 소구치의 발치보다 더 좋은 치료계획이 될 수 있 달.

본 증례에서 상악 견치의 이소맹출로 인하여 상악 절치의 치 근이 상당한 흡수를 보이고 있었다. 좌측 상악 절치는 이미 심 한 치근흡수로 장기간의 예후가 불량한 상태였고, 다른 인접한 치아의 치근흡수가 더 진행될 수도 있는 상태였다. 따라서 심한 치근흡수로 예후가 불량한 치아의 발치를 시행하고, 발치 부위 로 상악 견치의 맹출을 유도하였다. 이후 절치를 대체한 견치는 레진 수복을 시행하였다. 견치는 절치와 크기, 형태, 색상에서 차이가 분명하다. 하지만 날카로운 교두정의 삭제와 색조를 고 려한 복합레진 수복은 보철수복이 불가능한 성장기 어린이에게 심미적으로 만족을 줄 수 있는 치료 방법이 될 수 있다. 본 증례 는 이소맹출하는 상악 견치로 인해 심한 치근흡수를 보이는 예 후가 불량한 전치를 발거하고, 견치를 전치로 대체한 치료로 좋 은 결과를 보여 이에 대하여 보고하는 바이다.

\section{II. 증례보고}

\section{1. 증례 1}

13세 2개월 된 남자아이가 만기 잔존된 상악 좌측 유견치를 주소로 경희대학교 치과병원 소아치과에 내원하였다. 전신병력 이나 치아 외상병력은 없었으며, 파노라마 방사선 검사 결과 상 악 좌측 견치가 상악 좌측 중절치의 치근흡수를 동반하면서 중 절치에 가깝게 매복되어 있었다(Fig. 1). 환아의 상악 좌측 중 절치의 치근흡수 정도를 판단하기 위해서 컴퓨터 단층촬영을 시행하였다. 컴퓨터 단층촬영 결과에서 상악 좌측 중절치의 치 근은 $2 / 3$ 이상 흡수가 진행되었고, 상악 좌측 측절치도 치근흡 수 소견이 나타났다(Fig. 2). 중절치는 치근흡수가 심한 상태로 유지가 불가능한 것으로 판단되어서 발치가 결정되었다. 상악 좌측 유견치는 후속 영구치가 치근단 부위에 위치하지 않은 상

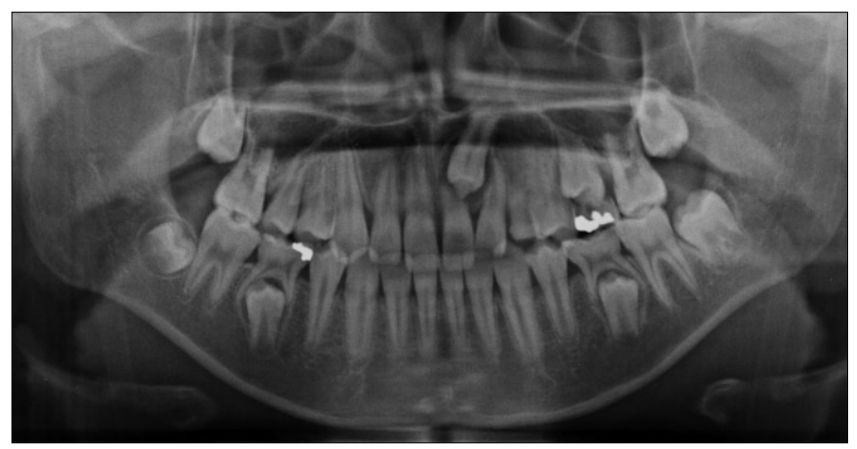

Fig. 1. Initial panoramic radiograph showing ectopically erupting maxillary left canine and external root resorption of maxillary left central incisor and lateral incisor.
태에서 이미 $1 / 2$ 정도의 치근흡수가 나타났고, 지속적인 치근 흡수가 나타날 것으로 예상되었다. 따라서 유견치의 발치를 시 행하고 측절치의 원심이동을 시행하여 견치의 맹출 공간을 확 보하였다.

국소마취 하에 상악 좌측 중절치와 상악 좌측 유견치의 발치 가 시행되었고, 일주일 후 견치의 맹출 공간을 확보하기 위해서 측절치의 원심이동을 위한 핑거 스프링(finger spring)이 장착 된 가철성 공간 유지장치(removable space maintainer)가 제 작되었다(Fig. 3,4$)$. 두 달 후에 측절치의 원심이동으로 견치 의 맹출을 위한 공간이 $10 \mathrm{~mm}$ 이상 확보되어서 가철성 공간 유지장치에 부착된 핑거 스프링을 제거하고, 가철성 공간 유지 장치의 인공치에 복합 레진을 접착하여 공간 손실을 예방하였 다. 4 개월 후 상악 좌측 중절치 위치에서 견치의 교두정이 나타 났으며, 견치의 맹출을 위해서 가철성 공간 유지 장치에서 인공 치의 치은 부위를 지속적으로 삭제하면서 견치의 맹출을 관찰 하였다. 11 개월 후 맹출한 견치를 복합레진(CHARISMA ${ }^{\circledR}$, Heraeus, Germany)을 이용하여 중절치의 형태로 수복하였다 (Fig. 5). 수복 후 정기적인 관찰을 통하여 맹출이 진행되는 견 치의 수복물을 수정하였다.
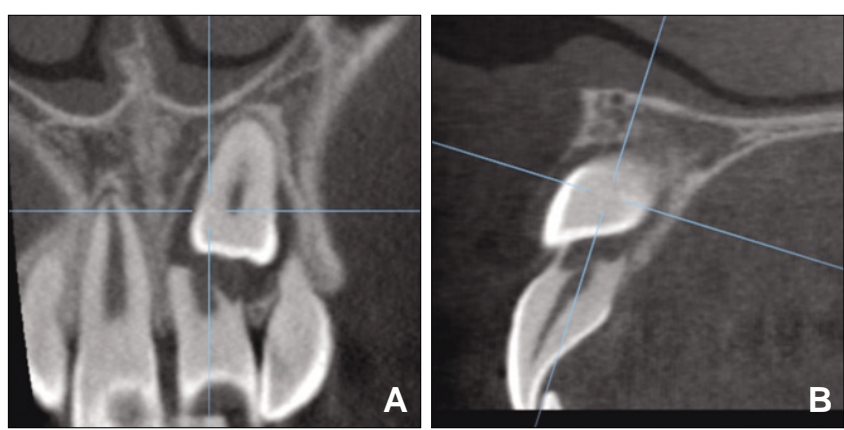

Fig. 2. Computerized tomographies showing severe root resorption of maxillary left central incisor and slight root resorption of the lateral incisor.

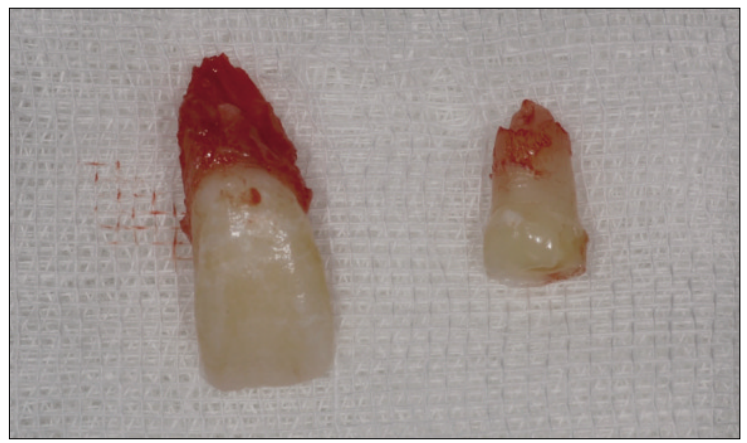

Fig. 3. The extracted maxillary central incisor and deciduous maxillary canine. The extracted maxillary central incisor root was resorbed to cervical third. 

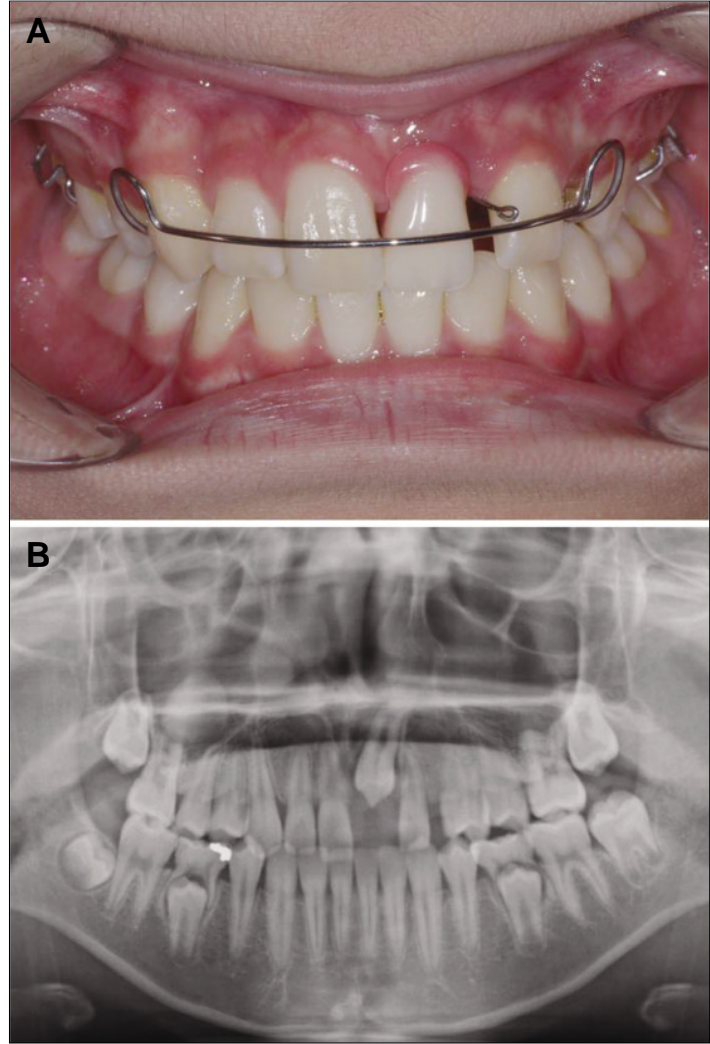

Fig. 4. Clinical intraoral photograph and panoramic view after two months. Removable space maintainer (RSM) with finger spring was delivered and the space for maxillary left canine was gained.
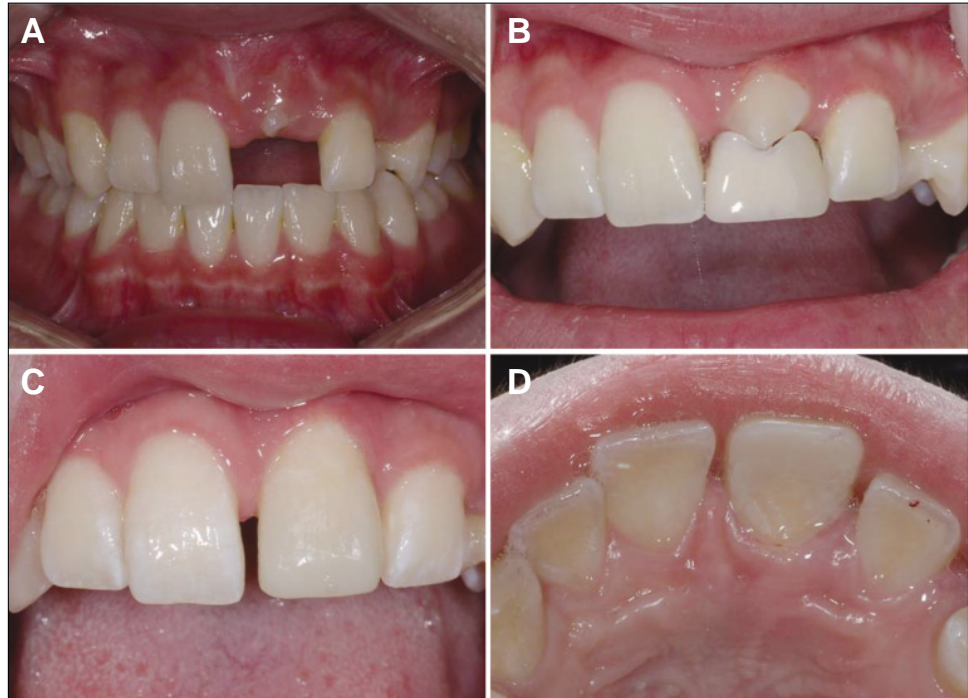

Fig. 5. Four months later, the cusp tip of canine was appeared in the position of central incisor. The pontic was gradually grinded as the physiological eruption of canine. Thirteen months later, the canine was reconstructed and reshaped to look like the central incisor.

\section{2. 증례 2}

8 세 10 개월 된 여자아이가 정기검진을 주소로 경희대학교 소 아치과에 내원하였다. 환아의 전신병력은 없었으며, 만 2세경 유전치 외상병력이 있었으나 영구 전치는 이상소견 없이 맹출 하였다.환아는 정기검진 중 방사선 검사에서상악 우측 견치가 상악 우측 측절치 방향으로 이소맹출하는 양상과 상악 우측 측
절치의 치근흡수 소견이 관찰되었다(Fig. 6). 상악 우측 측절치 는 심한 치근흡수로 자연 탈락이 예상되었고, 상악 우측 유견치 가 치근흡수 없이 유지되고 있었다. 견치를 위한 공간은 충분하 였고 상악 우측 측절치 부위로 자연스러운 맹출 경로를 보이고 있어 외과적 수술이나 교정적인 처치 없이 정기적으로 임상검 사를 시행하였다. 13 개월 후 내원 시 상악 우측 측절치는 자연 탈락되었고, 상악 우측 견치가 측절치 위치로 맹출 중이었다.

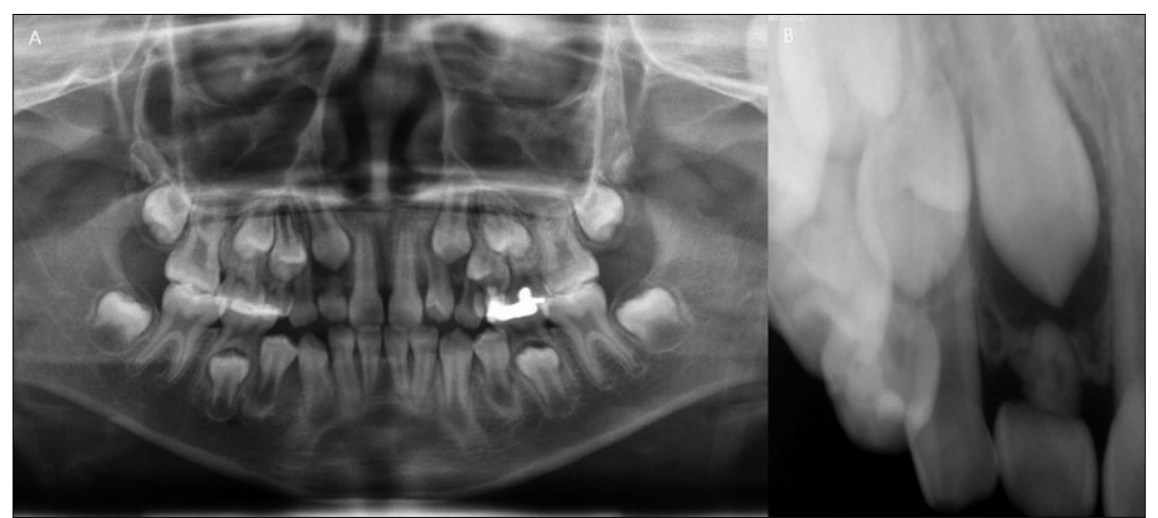

Fig. 6. Initial panoramic and periapical radiographic showing ectopically erupting maxillary right canine and external root resorption of maxillary right lateral incisor. 


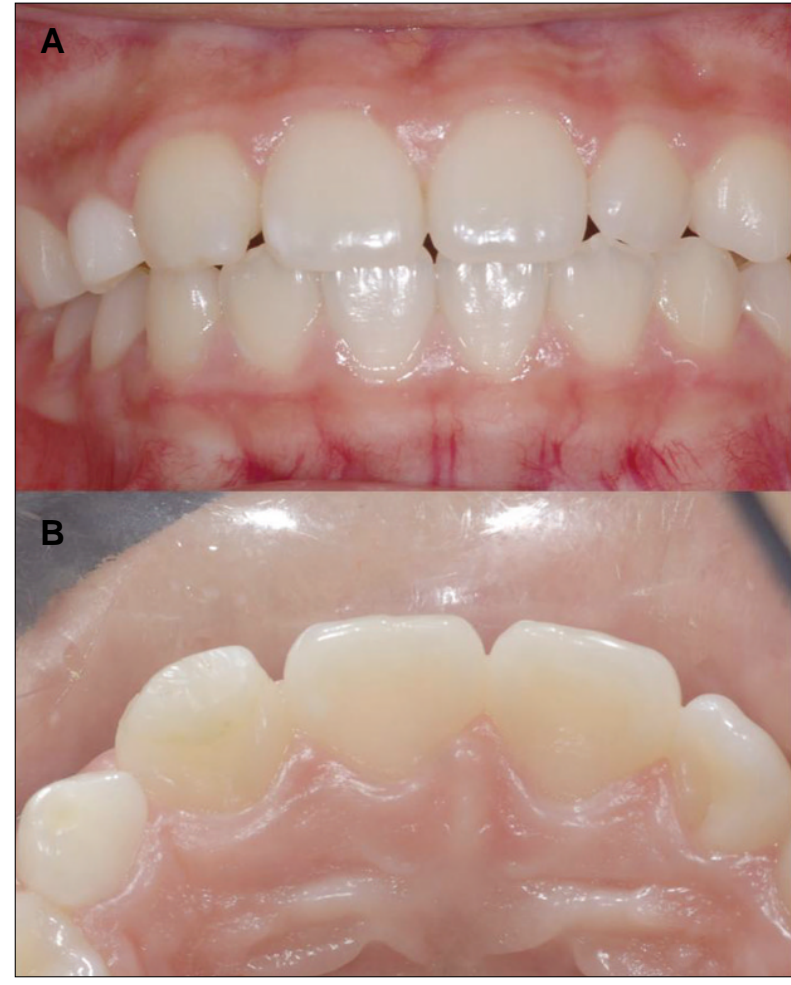

Fig. 7. Thirteen months later, maxillary right lateral incisor was exfoliated. Six months later, the canine was recontoured and reshaped to look like lateral incisor.
상악 우측 유견치는 치근흡수 없이 유지되고 있었다. 이후 6개 월 뒤 맹출한 상악 우측 견치는 복합레진(CHARISMA ${ }^{\circledR}$, Heraeus)을 이용하여 측절치의 형태로 수복되었다(Fig. 7). 성장 완료 후 상악 우측 유견치 발치 시 임플란트의 식립 또는 고정식 교정치료가 계획되었다. 5년 동안 정기적인 관찰을 시 행한 결과 상악 우측 유견치는 여전히 치근의 흡수 없이 유지되 고 있었으며, 견치도 측절치의 형태로 이상 없이 유지되고 있었 다(Fig. 8).

\section{III. 총괄 및 고찰}

매복된 상악 견치에 의한 상악 절치의 치근흡수는 과거에 치 근단 방사선 사진과 파노라마를 이용하여 진단하였으나, 현재 는 컴퓨터 단층촬영의 발달로 더 정밀한 관찰이 가능하여서 치 근 흡수의 발견 빈도가 약 $50 \%$ 증가하였다 ${ }^{5)}$. Ericson과 Kurol 의 컴퓨터 단층촬영을 이용한 치근흡수의 연구는 측절치와 중 절치에서 각각 $38 \%, 9 \%$ 의 치근흡수를 보고하였고, $\mathrm{Liu}$ 등은 210 개의 매복 견치를 연구한 결과에서 측절치와 중절치에서 각 각 $27 \%, 23 \%$ 의 치근흡수를 보고하였다 ${ }^{1.5)}$. 본 증례보고의 첫 번째 증례에서 컴퓨터 단층촬영을 통해 중절치와 측절치의 치 근흡수가 진단되었고, 치근흡수의 위치와 진행 정도를 판단하

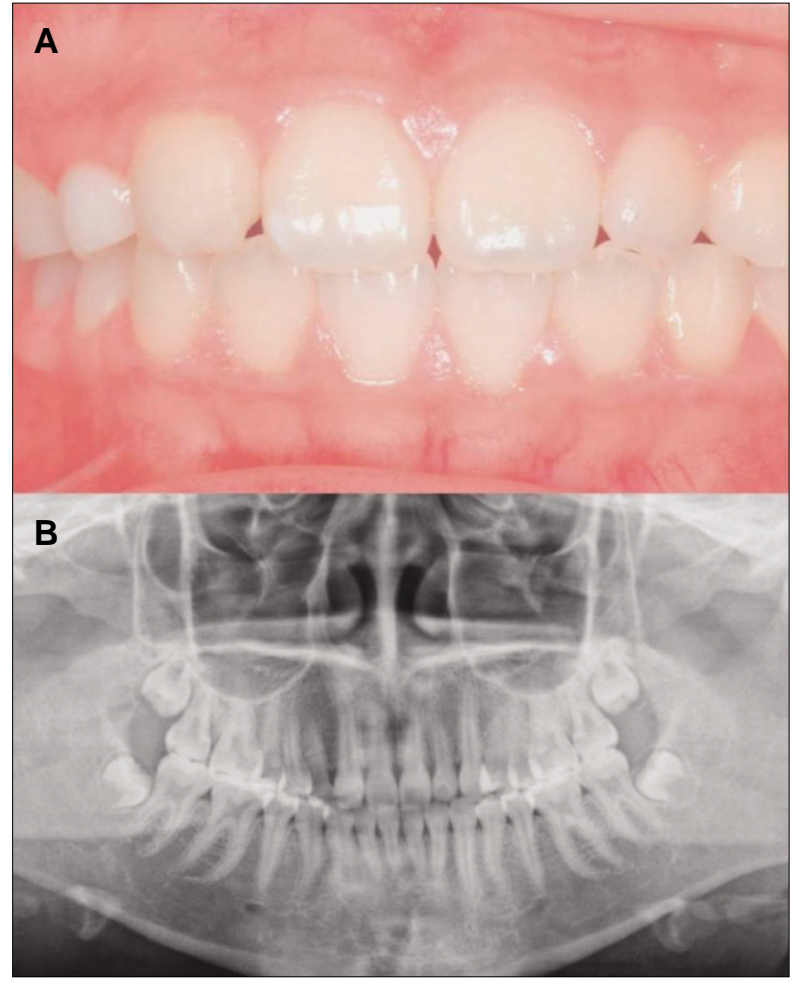

Fig. 8. 5-year later, intraoral and radiologic examinations showed no pathologic changes.
여 예후를 결정하였다.

매복된 상악 견치에 인접한 치아의 치근흡수를 일으킬 수 있 는 원인요소로는 유전적 요소, 외상, 특별한 습관 등이 고려되 고 있지만, 그 기전은 분명하게 밝혀져 있지 않다 ${ }^{6.7)}$. 하지만 대 부분의 저자들은 그 원인으로 상악 견치의 이동에 의한 물리적 압력을 강조하고 있다 ${ }^{1.5)}$. 압력에 의한 치근흡수는 매복치아에 의한 압력이 파골 세포(osteoclast)의 활성을 자극하고, 확장된 파골 세포가 박테리아의 감염이 없는 상태로 상아질에 부착하 여 반응하는 것으로 설명된달. 이 때 매복치아가 인접치아의 치근단공 근처에 위치하여서 치수의 혈액 공급을 방해하지 않 는다면 인접치아는 치수의 생활력이 존재하며, 방사선상 매복 치아의 근처에 치근흡수부위가 위치한담. 첫 번째 증례에서 매 복된 상악 좌측 견치의 치배는 상악 좌측 중절치와 측절치에 인 접해 있으면서 인접치의 치근흡수를 보인다. 이와 같은 치근흡 수 양상은 물리적 압력에 의한 치근흡수 기전 이론으로 설명이 가능하다. 두 번째 증례에서 매복된 상악 우측 견치의 치배와 상악 우측 측절치의 치근은 인접하여 있지만, 치근흡수가 치근 단 부위뿐만 아니라 치경부 부위에서도 나타나는 양상을 보이 고 있다. 이는 매복된 견치의 확장된 치배에 의해서 치근단 부 위의 치근 외흡수가 나타나고, 골개조 신호가 파치세포의 분화 에 관여하여서 치아의 내흡수를 유발한 것으로 생각된다. 
치근흡수된 치아의 예후는 치근흡수의 정도와 위치에 의해서 영향을 받는다. 치근흡수의 정도는 흡수의 진행 깊이에 따라서 경도(slight) · 중등도(moderate) · 중증 (severe)으로 분류된 다. 경도는 상아질 두께 절반 정도의 흡수, 중등도는 치수 경계 는 넘지 않으면서 치수까지의 중간 또는 그 이상의 흡수, 중증 은 치수가 노출된 경우를 의미한다 ${ }^{9}$. 치근 흡수된 치아는 치근 흡수의 정도가 경도에서 중등도인 경우 흡수 부위 주변으로 보 호하는 조직이 재형성되어서 비교적 좋은 예후를 보이고, 치수 를 포함하는 중증의 흡수를 보이는 경우 예후는 좋지 않고 치아 는 치유되기 힘들다.'. 예후에 영향을 주는 또 다른 요소인 치근 흡수의 위치는 치근단 $1 / 3$ 과 중간 $1 / 3$ 에서 빈번하며, 치경부 $1 / 3$ 에서 측절치 $5 \%$, 중절치 $7 \%$ 의 낮은 빈도로 나타난다 ${ }^{5}$. 치 경부 $1 / 3$ 위치에서의 치근흡수는 적은 빈도로 나타나지만 치근 흡수가 진행된 경우 치아 동요도가 나타날 수 있고 예후가 좋지 않다. 첫 번째 증례에서 상악 좌측 중절치는 중증의 치근흡수가 치경부 $1 / 3$ 위치까지 진행되고, 상악 좌측 측절치에 경도의 치 근흡수가 나타난 상태로 내원하였다. 치경부 $1 / 3$ 까지의 치근흡 수를 보이는 중절치 경우 장기간의 예후는 불분명하고, 측절치 는 치근흡수가 지속될 수 있는 상태로 판단되었다. 따라서 예후 를 보장할 수 없는 중절치의 발치를 시행하였고 측절치를 원심 이동 하여서 치근흡수의 진행을 정지시켰다. 두 번째 증례에서 도 우측 측절치는 중증의 치근흡수로 치경부 $1 / 3$ 까지 진행되었 으며 내흡수로 인한 치경부 치근흡수도 나타난 상태였다. 이미 흡수가 진행된 측절치는 장기간 유지되지 못할 것으로 판단되 었지만, 심미와 공간유지를 위하여 최대한 유지하다가 맹출하 는 견치에 의해서 자연 탈락하였다.

매복된 상악 견치의 치료 방법은 유견치의 조기 발거와 같은 차단 교정, 수술적 노출을 동반한 교정적 배열, 자가치아이식술 과 매복치아의 발치를 포함한다 ${ }^{10)}$. 치료방법은 환자의 나이와 수술의 포함 여부, 전반적인 구강 상태, 매복의 형태, 잉여 공간 과 공간 부족의 존재 여부에 따라 달라지고 인접치아의 흡수와 낭종성 변성과 같은 합병증과도 연관되어 있다 ${ }^{11}$. 매복 상악 견 치로 인한 합병증을 줄이기 위해서는 매복 견치의 조기 발견, 치근흡수의 진단과 정도의 평가를 통한 예방이나 초기 개입이 중요하다. 따라서 9 세에서 11 세까지 상악 견치의 맹출에 대한 주의 깊은 임상적 관찰이 추천된다.9. 첫 번째 증례에서 환아는 만 13 세 2 개월에 본원에 내원하였으며, 이미 좌측 상악 견치의 이소맹출과 좌측 상악 중절치의 치근흡수가 상당히 진행된 상 태였다. 이 증례의 경우 조기에 발견되었을 경우 차단 교정이나 수술적 노출을 동반한 교정적 배열 등의 조기 처치를 통하여 중 절치와 견치의 유지가 가능했지만, 내원 시조기 치료는 불가능 한 상태였다. 또한 진단을 받은 시점에서 수술적 노출을 동반한 교정적 배열을 시행하기에 견치의 위치가 추가적인 측절치의 치근흡수 등의 합병증을 유발할 수 있으므로, 중절치를 발거하 고 견치를 중절치로 사용하였다.두 번째 증례는 비교적 이른 시 기인 만 8 세 10 개월에 우측 상악 견치의 이소 맹출과 측절치의 치근흡수가 발견되었지만, 측절치의 치근흡수가 심하게 진행되 어있어서 조기 처치가 불가능하였다. 따라서 견치를 측절치로
사용하고, 유견치를 유지하는 치료계획이 세워졌다. 본 증례에 서 치근흡수된 인접치아의 위치에 견치를 사용하는 경우, 치근 흡수된 치아의 불안정한 예후를 피할 수 있고 외과적 노출을 동 반한 교정적 배열을 시행하는 것보다 비용과 시간의 절감을 얻 을 수 있다는 장점을 가진다.

견치를 절치로 사용시 포세린 부분 피개관이나 전장관 수복 은 복합레진을 이용한 수복보다 심미적이고 자연스러운 형태를 나타낸다. 하지만 복합레진을 이용한 수복은 경제적이고, 아직 성장이 완료되지 않아서 보철 수복이 효과적이지 않은 환자에 게 유용할 수 있으므로 추천될 수 있다. 단 복합레진을 이용한 수복의 경우에 견치의 색상과 크기가 절치와 차이가 있기 때문 에 완전한 절치의 형태를 재현하는데 한계가 있다. 본 두 증례 에서 치아의 크기나 색상에 약간의 차이는 존재하지만 환자와 보호자는 심미적으로 만족하였다. 복합레진으로 수복된 견치는 지속적인 관찰을 통하여서 맹출에 따른 연마를 시행하여야 하 고, 만 18세 이후에 보철 수복으로 변경하거나 현재의 상태를 유지할 수 있다. 견치를 절치로의 사용에서 또 다른 심미적 고 려사항은 견치 부위에 치조골의 두께가 소실되는 문제이다. 첫 번째 증례에서 견치의 손실부위에 공간이 존재하여서 견치부위 에 치조골의 두께가 감소하였다. 이 증례의 경우 차후 교정치료 를 통한 공간의 폐쇄 또는 교정치료 후 임플란트가 계획되어있 다. 교정치료를 통하여서 전치부에 존재하는 공간의 폐쇄와 견 치부위로 소구치의 이동이 시행될 것이고, 소구치의 존재로 소 실된 견치부위의 치조골의 두께는 회복될 것이다. 두 번째 증례 의 경우 유견치가 존재하여서 견치부위에 치조골의 두께는 유 지되고 있다. 이 증례에서 환아는 성장완료 시까지 치조골의 손 실을 막기 위해서 유견치를 유지하고, 성장이 완료된 후에 유견 치의 발거와 임플란트 치료가 계획되어 있다. 향후 견치부위는 임플란트의 식립으로 치조골의 두께를 유지할 수 있다.

\section{IV. 요 약}

이소맹출하는 견치의 초기 처치는 가장 좋은 결과를 가져오 지만 인접치아에 이미 심한 치근흡수를 일으켰다면, 잘못 위치 한 견치가 손상된 치아를 대체할 수 있다. 보고한 증례들에서 이소맹출과 인접치아의 치근흡수가 조기에 진단되었다면 합병 증을 감소시킬 수 있었을 것이다. 하지만 그렇지 못한 경우에 이소맹출하는 견치를 상악 절치로 대체 사용하는 것을 대안으 로 선택할 수 있다.

\section{References}

1. Liu DG, Zhang WL, Ma XC, et al. : Localization of impacted maxillary canines and observation of adjacent incisor resorption with cone-beam computed tomography. Oral Surg Oral Med Oral Pathol Oral Radiol Endod, 105:91-98, 2008.

2. Alqerban A, Jacobs R, Willems G, et al. : Root 
resorption of the maxillary lateral incisor caused by impacted canine: a literature review. Clinical Oral Invest, 13:247-255, 2009.

3. Shafer WG, Hine MK, Levy BM : A textbook of oral pathology, $4^{\text {th }}$ edition. W.B. Sauders, Philadelphia, 1984

4. Ericson S, Kurol J : Radiographic examination of ectopically erupting maxillary canines. Am J Orthod Dentofacial Orthop, 91:483-492, 1987.

5. Ericson S, Kurol J : Resorption of Incisors After Ectopic Eruption of Maxillary Canines: A CT Study. Angle Orthodontist, 70:415-423, 2000.

6. Ericson S, Kurol J : Incisor root resorptions due to ectopic maxillary canines imaged by computerized tomography: a comparative study in extracted teeth. Angle Orthod, 70:276-283, 2000.

7. Knight $\mathrm{H}$ : Tooth resorption associated with the eruption of maxillary canines. Br J Orthod, 14:2131, 1987.

8. Fuss Z, Tsesis I, Lin S : Root resorption-diagnosis, classification and treatment choices based on stimulation factors. Dental Traumatology, 19:175-182, 2003.

9. Falahat B, Ericson S, Mak D’Amico R, Bjerklin K : Incisor root resorption due to ectopic maxillary canines: a long-term radiographic follow-up. Angle Orthodontist, 78:778-785, 2008.

10. Bedoya MM, Park JH : A review of the diagnosis and management of impacted maxillary canines. JADA, 140:1485-1493, 2009.

11. Jacobs SG : The impacted maxillary canine. Further observations on aetiology, radiographic localization, prevention/interception of impaction, and when to suspect impaction. Aust Dent J, 41:310-316, 1996. 
국문초록

\section{이소맹출하는 견치의 상악 전치로의 대체사용 : 증례보고 \\ 임지은 · 최성철 · 박재홍 · 최영철 · 김광철 · 안효정 \\ 경희대학교 치과의학전문대학원 소아치과학교실, 구강생물학연구소}

매복된 상악 견치는 제 3대구치 다음으로 호발하는 매복치아로 정확한 원인은 알려져 있지 않으나 매복된 상악 견치로 인 한 다양한 합병증이 나타날 수 있다.

이소맹출하는 상악 견치는 초기의 진단을 통하여 유견치의 조기 발거와 같은 차단 교정을 시행하는 경우 가장 좋은 예후를 보일 수 있으나 초기치료를 시행하지 못한 경우에는 수술적 노출과 교정적 치료를 고려할 수 있다. 또한 이소맹출하는 치아 가 말기에 발견되어서 인접치아의 심한 흡수를 보인다면, 견치가 손상된 인접 치아를 대체할 수 있다.

본 증례들은 이소맹출과 치근흡수의 조기 진단을 통하여 치료되지 못한 증례로 이소맹출하는 견치를 사용하여 상악 절치의 대체사용이 대안으로 선택되었고, 현재까지 성공적인 결과를 보인다. 복합레진으로 수복된 견치는 지속적인 관찰을 통하여서 수복물을 평가할 예정이며, 추후 교정치료와 임플란트의 식립이 계획되어있다.

본 증례는 초기 처치가 이루어지지 않은 경우에 견치를 절치로 대체 사용하여 치근 흡수된 치아의 불확실한 예후를 피하 고, 시간과 비용을 절감하여 심미적 만족을 얻을 수 있는 방법에 대하여 보고하고자 한다.

주요어: 이소맹출, 매복견치, 치근흡수 